\title{
Шнюкова Р.П.
}

\section{Технологии творческой мастерской как эффективная форма художественно-творческой самореализации личности школьника на занятиях изобразительного искусства}

\author{
Shnyukova R.P. \\ Technology creative workshop as an effective form \\ of artistic and creative self-realization of the \\ schoolboy in the classroom of the fine arts
}

Технологии творческой мастерской направлены на повышение уровня художественного образования и воспитания, на развитие креативного, творческое мышление учащихся. Технологии творческой мастерской позволяют раскрыть индивидуальность, способности учащихся в области научно-исследовательской, проектной, художественно-творческой деятельности, готовит к активному преобразованию окружающей действительности

Ключевые слова: творческие способности, креативное творческое мышление, индивидуальность

\section{Шнюкова Раиса Петровна}

Доцент, заведующая кафедрой

Ставропольский государственный педагогический институт

2. Ставрополь, ул. Ленина, 417 A
Technology creative workshop aimed at raising the level of artistic education and training, for the development of creative, creative thinking of students. Technology creative workshop can reveal personality, the ability of students in the field of scientific research, design, artistic and creative activity, is preparing to take an active transformation of reality

Key words: creativity, creative creative thinking, personality
Shnyukova Raisa Petrovna
Associate Professor, Head of Department
Stavropol state pedagogical institute
Stavropol, Lenin st., 417 A

Современному обществу требуется не только квалифицированный в своей области специалист, но и личность творческая, разносторонняя, культурно образованная. Современный успешный человек - это, прежде всего, гармоничная личность, которая знает и ценит свои истоки, свою культуру. Национальная доктрина образования Российской федерации указывает на необходимость выявления творческого потенциала личности, развития ее способностей и формирования условий её самореализации.

Нынешняя система образования особое внимание уделяет проблеме поиска более эффективных средств и путей повышения качества образования и 
воспитания учащихся. Новому качеству образования требуются, новые инновационные технологии.

Творческие мастерские - это эффективная форма организации учебной деятельности учащихся, на уроках изобразительного искусства кардинально отличающаяся от обычного урока. В творческих мастерских ученик не получает готовых знаний, он их добывает, сам выстраивает траекторию своего познания. Эта технология, разработанная «Французской группой нового образования», Поль Ланжевен, Анри Валлон, Жан Пиаже и др. обращена к ребенку, к его интересам, к его индивидуальности [3; с. 132-136].

Методика творческой мастерской позволяет создать на занятиях изобразительного искусства атмосферу творческого поиска, доверия, сотрудничества, проявления индивидуальности, личного опыта учащихся на основе связи с другими дисциплинами, видами и жанрами изобразительного искусства. Творческая мастерская для учащихся - это неограниченные возможности для развития креативного творческого мышления, художественного воспитания и образования.

Технология творческой мастерской учит учащихся думать, творить, фантазировать, мыслить смело и свободно, нестандартно, в полной мере проявлять свои способности, развивать уверенность в себе, в своих силах, освободиться от конфликтов и сильных переживаний, быть самим собой, свободно выражать мысли и чувства.

Из действующих педагогических методов работы творческая мастерская близка к проблемным и исследовательским методам обучения. Педагогический процесс выстраивается по методу проектирования, который позволяет раскрыть индивидуальность каждого учащегося, его способности в научно исследовательской, проектной, конкурсной и художественно-творческой деятельности [1;с.11].

Технология творческой мастерской основывается на совместной деятельности педагога и учащегося, где выбор направления художественнотворческой деятельности осуществляет ученик, а педагог выступает в роли консультанта и координирует ход его работы. Учащийся самостоятельно определяет какому жанру изобразительного искусства отдать предпочтение, планирует свою деятельность: создает замысел, выполняет эскиз, выбирает материал, а затем приступает к воплощению творческого проекта. Каждый ученик в творческой мастерской - это художник, самостоятельно создающий творческую композицию. Каждая работа, выполняемая по методу творческой мастерской, это - проект, законченное произведение, которое учащиеся представляют на просмотры, выставки, конкурсы или олимпиады [4;с.27].

Работа на занятиях изобразительного искусства по методу творческой мастерской позволяет освоить одновременно огромное количество материалов и техник, что невозможно осуществить в традиционном учебном процессе: рисование по мокрой бумаге, пластилинография, предметная и пейзажная монотипия, рисование мятой бумагой, рисование с использованием соли, рисование ватой по бархатной бумаге, кляксография с трубочкой, рисование воско- 
выми мелками, печатание, рисование песком, техника резервирования, обрывание бумаги, и др.

Планирование работы в творческой мастерской ведется с учетом интересов учащихся, индивидуальных образовательных планов. Педагог должен учитывать не только уже имеющиеся у учащихся знания, умения и навыки, но и наметить пути их роста, совершенствования и приобретения новых знаний, практических умений, знакомить их с новыми материалами и технологиями.

В педагогической технологии творческих мастерских используются различные способы обучения: групповой, парный и индивидуальный. Здесь на первый план выдвигается личность самого обучающегося, который сталкиваясь с проблемой, сам конкретизирует её, формулирует задачи, сам ищет пути их решения, выделяет проблемы, которые необходимо обсудить. Следовательно, он отвечает не только за свои знания, но и за организацию самого процесса познания. Таким образом, создаются условия для сотрудничества и созидательной художественно-творческой деятельности. Творческая мастерская как педагогическая технология направлена на раскрытие и проявление индивидуальности учащегося на его общее развитие, на развитие его творческих способностей, исследовательской культуры. Творческая мастерская рассматривается как педагогическая технология, соответствующая современным подходам в художественном образовании и воспитании учащихся: компетентностному, гуманистическому, субъектному, педагогике успеха, педагогике сотрудничества [2;с.65].

Педагог продумывает тематику заданий по изобразительному искусству таким образом, чтобы постепенно углублять знания, совершенствовать практические изобразительные навыки учащихся, пробуждать инициативность, самостоятельность в принятии решений. Роль учителя заключается в том, чтобы построить занятие с учащимися таким образом, чтобы каждый смог создать и реализовать замысел творческого проекта, чтобы каждый почувствовал уверенность и свободу самовыражения. Повышение склонности к изобразительной деятельности является показателем роста способностей учащихся к художественному творчеству и развитием к нему интереса. А развить интерес к творчеству у каждой отдельной личности можно только с учетом индивидуальных способностей. Для развития познавательного интереса к изобразительной деятельности, для более прочного усвоения знаний, умений и навыков необходимо применять нестандартные подходы в обучении

Творческие мастерские на занятиях изобразительного искусства выступают как совокупность пространств: учебного, игрового, художественнотворческого, культурного, где учащиеся приобретают жизненный опыт, опыт художественного освоения мира, сами выстраивают собственные знания, познают общекультурные ценности.

Одной из основных задач школы является формирование у учащихся творческого и познавательного процессов, готовности к активному преобразованию окружающей действительности. Это позволяет выдвинуть предмет изобразительное искусство на один из первых планов, как основу для развития творческой, созидающей личности в целом. 
Список используемых источников:

1. Беспалько В.П. Слагаемые педагогической технологии. М.: Педагогика, 1989. С. 10-35.

2. Гузеев В.В. Лекции по педтехнологии. М.: Знание, 1992.

3. Джуринский А.Н. Новые технологии в системе образования Франции // Советская педагогика. 1991. №4. С. $132-136$.

4. Окунев А.А. Урок. Мастерская. СПб.: Просвещение, 2001. С. 20-55.

(C) 2015, Шнюкова Р.П.

Технологии творческой мастерской как эффективная форма художественно-творческой самореализации личности школьника на занятиях изобразительного искусства
(C) 2015, Shnyukova R.P.

Technology creative workshop as an effective form of artistic and creative self-realization of the schoolboy in the classroom of the fine arts 